\title{
Geometry, kinematics, and magnitude of extension across the Thakkhola Graben, Central Nepal Himalaya
}

\author{
Thomas Baltz ${ }^{1, *}$, Michael Murphy ${ }^{1}$, Suoya Fan ${ }^{1}$, Deepak Chamlagain ${ }^{2}$ \\ ${ }^{1}$ Department of Earth and Atmospheric Sciences, University of Houston, Houston, Texas 77204, USA \\ ${ }^{2}$ Department of Geology, Tri-Chandra M. Campus, Tribhuvan University, Kathmandu, Nepal \\ *Corresponding author's email: tkbaltz@gmail.com
}

\begin{abstract}
The Thakkhola Graben has been a region of geologic inquiry for many decades. Although it is widely viewed to be in a class of structures that are important in accommodating the three-dimensional strain within the Himalayan thrust wedge, we still lack a detailed understanding of the total finite strain accommodated by graben-bounding faults, as well as their shape and cross-cutting relationships with structures deeper in the thrust wedge. Using geologic mapping and structural analysis, we show that a suite of pre-extensional shortening structures is offset by normal-oblique faults bounding the Thakkhola Graben that we use to define a piercing line. By restoring this piercing line, we calculate these faults to have accommodated 8.7 kilometers of vertical thinning, 7.2 kilometers of arc-perpendicular shear, and only 2.2 kilometers of arc-parallel extension. The magnitude of arc-parallel extension is quite low compared to extensional structures to the west in the Gurla Mandhata-Humla region. The cross-cutting relationships established in this study and timing constraints determined by previous works are consistent with a structural history of crustal thickening leading to foreland propagation of the locus of arc-perpendicular shortening contemporaneous with hinterland extension.
\end{abstract}

Keywords: Himalaya; Extension; Graben; Geometry; Kinematics

Received: 23 February, 2021 Received in revised form: 11 July, 2021 Accepted: 12 July, 2021

\section{INTRODUCTION}

Within the Himalayan thrust wedge several structures accommodate extension parallel to the strike of the orogen (Fig. 1). These structures are significant components of orogen-scale kinematic and mechanical models which attempt to explain active extension of the crust during convergence: e.g., lateral extrusion (Replumaz and Tapponnier, 2003), oroclinal bending (Klootwijk et al., 1985; Ratschbacher et al., 1994; Schill et al., 2004), gravitational collapse (Burchfiel and Royden, 1985), radial spreading (Jade et al., 2004; Murphy and Copeland, 2005; Copley and McKenzie, 2007), and oblique convergence (McCaffrey and Nabelek, 1998; Seeber and Pêcher, 1998; Fan and Murphy, 2021). In central Nepal arc-parallel extension is accommodated by the Thakkhola Graben. Despite decades of research (e.g. Hagen, 1959; Bassoullet and Colchen, 1974; Colchen et al., 1980; Fort et al., 1982; Hurtado et al., 2001; Godin, 2003) the magnitude of strain accommodated by Thakkhola Graben structures remains uncertain. Predictions based on regional palinspastic reconstructions estimate as much as 45 kilometers of slip may have been accommodated here (Replumaz and Tapponnier, 2003); field expeditions reveal as little as 2-5 kilometers (Colchen et al., 1986; Colchen, 1999; Hurtado et al., 2001). Determining the magnitude of arc-parallel extension accommodated by Thakkhola Graben faults is essential to assessing kinematic models of the thrust wedge. In particular, Thakkhola Graben's central position with respect to the orogen makes it a good location to test the predictions of the oblique convergence model. In central Nepal, where the convergence obliquity is low, this model predicts a decrease in the magnitude of arcparallel strain compared to extensional structures to the west. This paper presents a field-based structural study of Thakkhola Graben aimed at constraining the kinematics and magnitude of slip accommodated by the graben-bounding faults. Additionally, evaluating the sequence of Miocene regional deformation will clarify the state of stress in the upper crust immediately prior to, and during, the graben's development.

\section{Geologic Setting and Previous Work}

The Himalayan thrust wedge is composed of regionally continuous, shear-zone-bounded tectonostratigraphic units. These units are, from north to south: the Tethyan Sedimentary sequence (TSS), the Greater Himalayan Crystalline series (GHC), the Lesser Himalayan Sequence (LHS), and the Sub-Himalayan Sequence (SHS). They are separated by the South Tibetan Detachment System (STDS), the Main Central Thrust (MCT), and the Main Boundary Thrust (MBT), respectively (Figs. 1 and 2). The SHS is actively 


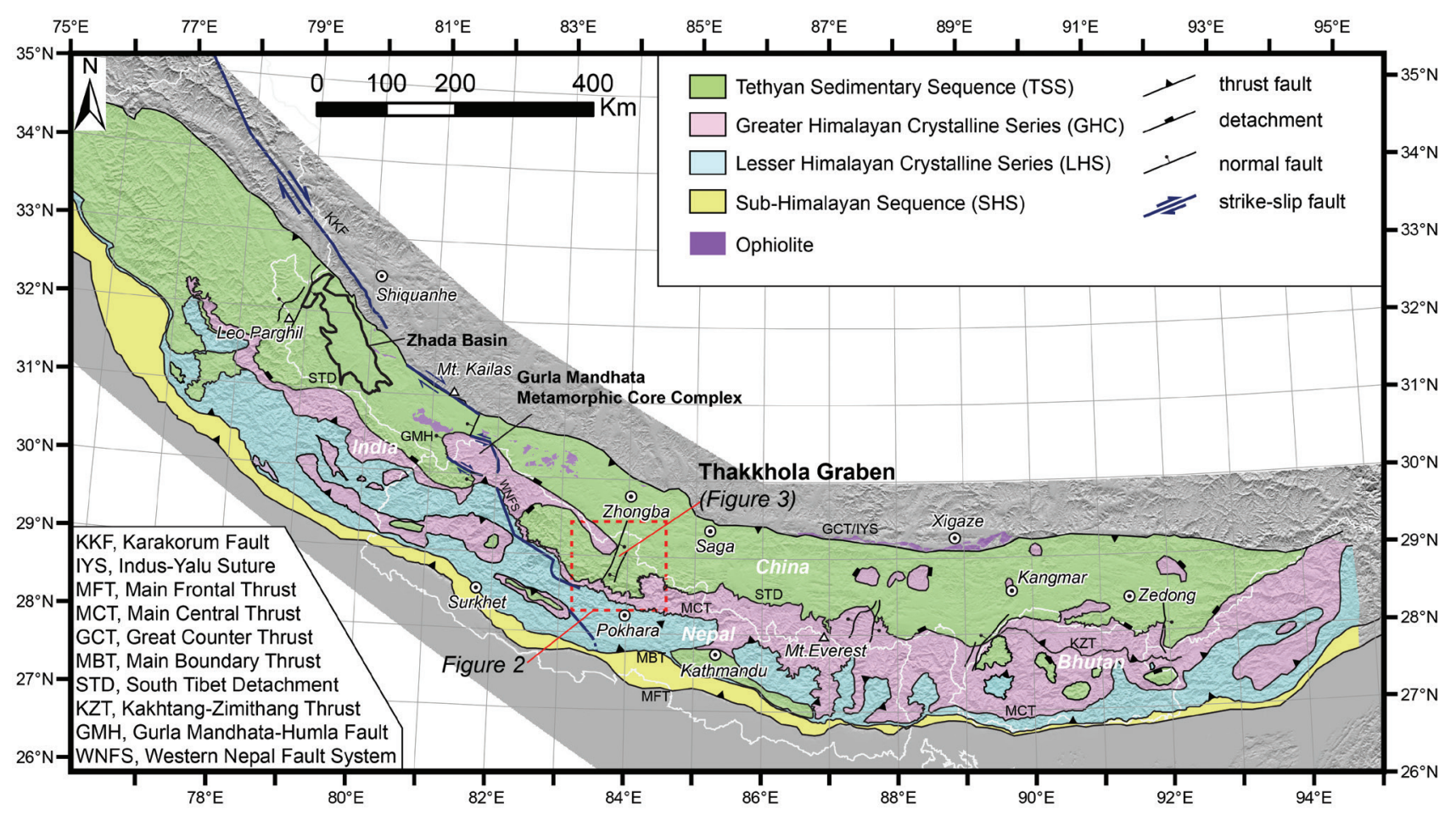

Fig. 1: Simplified tectonic map of the Himalayas and southern Tibet. Modified after Fan and Murphy (2021).

thrust over modern sediments along the Main Frontal Thrust (MFT). The aforementioned thrust faults sole into the Main Himalayan Thrust (MHT), which accommodates most of the convergence between India and Asia (Gansser, 1964; Molnar, 1984; Burchfiel et al., 1992; Zhao et al., 1993; Upreti, 1999). Two major leucogranite bodies are recognized in the Himalaya and southern Tibet: the High Himalayan granite belt and the Northern Himalayan granite belt (Debon et al., 1981; Le Fort, 1981; Schärer et al., 1986; Le Fort et al., 1987; Harrison et al., 1997). The former is typically observed at the crest of the Himalaya intruding high-grade GHC beneath the STDS (Murphy and Harrison, 1999; Searle and Godin, 2003) and the latter intrudes the TSS (Debon et al., 1986; Le Fort, 1986). The Thakkhola Graben extends from southern Tibet to the mid portion of the Himalayan thrust wedge in the hanging wall of the Annapurna Detachment (AD), a segment of the STDS (Caby et al., 1983; Brown and Nazarchuk, 1993). The faults bounding the graben, the Dangardzang Fault in the west and the Muktinath Fault in the east, offset the TSS and the Mustang leucogranite (Hagen, 1954; Fuchs, 1964; Hagen, 1969; Colchen et al., 1986; Le Fort and France-Lanord, 1995) (Fig. 2). Thakkhola Graben terminates to the north near the Indus-Yalu Suture (Heim and Gansser, 1939) and Great Counter Thrust (Yin et al., 1999) (Fig. 1). West of Thakkhola Graben is the Western Nepal Fault System (Murphy et al., 2014; Silver et al., 2015) and the Gurla MandhataHumla Detachment (GMH) (Murphy and Copeland, 2005), both of which are interpreted to link with the Karakoram strike-slip fault (Murphy et al., 2000).
East of Thakkhola is the Manaslu leucogranite in the footwall of the STDS, both of which are folded into a crustal-scale anticlinorium-synclinorium (Le Fort, 1981; Harrison et al., 1999; Searle and Godin, 2003). Similar folding is observed in the Dolpo region between Thakkhola Graben and the GMH (Fuchs and Sinha, 1974; Cannon and Murphy, 2014; Fan and Murphy, 2021) (Fig. 2).

The Kali Gandaki River has carved a deep gorge along the length of Thakkhola Graben and between the Annapurna and Dhaulagiri Ranges to the south, exposing a nearly continuous section of the tectonostratigraphic units (Fig. 2). Along this river valley some of the earliest Himalayan expeditions described and correlated the major tectonic boundaries and rock units (Strachey, 1851; Auden, 1937; Heim and Gansser, 1939; Hagen, 1959; Hagen et al., 1961; Gansser, 1964). French and German teams explored the Annapurna and Dhaulagiri Ranges and found their peaks were composed of the same TSS rocks observed to the north in Tibet (Ichac and Pruvost, 1951; Bodenhausen et al., 1964; Gansser, 1964). An expedition to the northern slope of Dhaulagiri reported WNW-striking synclines in the TSS of the southwest Thakkhola Graben footwall (Fuchs, 1964). These synclines, commonly cored by reverse faults, are cross-cut by the western graben-bounding fault. The Mustang leucogranite, the eastern portion of the Dolpo-Mugu batholith, was observed to be cut along this fault (Le Fort and France-Lanord, 1995).

Over the next several decades researchers worked their way north into Thakkhola Graben as they 




Fig. 2: Regional Geologic map of central Nepal and southern Tibet modified from the Geological Map of Nepal (2002) and Searle and Godin (2003). The bounding faults of Thakkhola Graben offset the Dolpo-Mugu-Manang anticlinorium-synclinorium, TSS, Mustang Detachment, GHS, and Mustang leucogranite. The Mustang Detachment is interpreted to be associated with the STDS, correlative with the Annapurna and Phu Detachments. DMMA: Dolpo-Mugu-Manang Anticlinorium; DMMS: Dolpo-Mugu-Manang Synclinorium.

characterized the LHS, GHC, TSS, and a complex sequence of deformation (e.g. Fuchs, 1964; Bordet et al., 1971; Bordet, 1972; Colchen, 1975; Le Fort, 1975; Bordet, 1977; Fuchs, 1977; Colchen, 1981; Colchen et al., 1986; Brown and Nazarchuk, 1993). Bassoullet and Colchen (1974) and Colchen et al. (1979) described the graben-fill formations, the Thakkhola Formation and the underlying Tetang Formation, which they observed to be separated by an angular unconformity. They interpreted that these formations are dominantly fluvial interlayered with lacustrine limestone and landslide deposits, and are derived from exhumation of rocks in adjacent mountains. Fort (1980) observed these basin-fill sediments in buttress unconformity with the underlying folded TSS and partial erosion of the Tetang Formation prior to deposition of the Thakkhola Formation after a change in sediment source direction from east to west. This implies deformation began on the eastern side of the graben and transferred to the western side after a hiatus. An expedition into the Annapurna-Manaslu region produced a detailed map of the folded TSS in the footwall of the eastern graben-bounding fault (Colchen et al., 1986). Units comprising the top of the TSS are found in the southwest portion of the graben (Garzanti et al., 1999). Gradstein et al. (1992) provides a comprehensive lithologic description of the TSS.

Subsequent work in this region focused on the kinematics of the Annapurna Detachment (AD) and its relationship to the complexly folded TSS in its hanging wall. The AD is a ductile shear zone that has accommodated top-to-the-northeast displacement of the TSS (Caby et al., 1983; Brown and Nazarchuk, 1993). Hodges et al. (1996) describe an initial phase of shortening along the AD prior to extension and suggested that it was contemporaneous with activity along the MCT. The TSS experienced multiple phases of deformation resulting in kilometer-scale folds overprinted by at least two more generations of folds (Bordet et al., 1971; Le Fort, 1975; Colchen, 1981). Godin (2003) describes several deformation phases responsible for the structures within the TSS: $\left(D_{1}\right)$ 
Baltz et al.

initial south-verging folds, $\left(\mathrm{D}_{2}\right)$ north-verging back folding, $\left(D_{3}\right)$ shear associated with the brittle upper $\mathrm{AD},\left(\mathrm{D}_{4}\right)$ south-verging compressional deformation, and $\left(\mathrm{D}_{5}\right)$ Thakkhola Graben formation. These events resulted in $150 \%$ thickening of the TSS, up to 25 kilometers, and kyanite-grade metamorphism in the underlying GHC ca. 35 Ma (Godin et al., 2001; Godin, 2003). This is consistent with paleoaltimetry results showing the Himalayan hinterland has maintained high elevation since at least the late Miocene (Garzione et al., 2000). Activity along the STDS during $\mathrm{D}_{3}$ is associated with emplacement of the Manaslu leucogranite in the Marsayandi Valley to the east. The STDS was subsequently folded into a 400 kilometer wide crustal-scale anticlinoriumsynclinorium pair (Searle and Godin, 2003; Fan and Murphy, 2021) (Fig. 2). At the surface, extensional faults related to Thakkhola Graben are observed near the $\mathrm{AD}$ but do not appear to deform the underlying GHC (Godin et al., 1999; Hodges et al., 2001; Godin, 2003).

The initiation of east-west extension in this region is estimated to be as early as $14 \mathrm{Ma}$ and magnetostratigraphy of the basin fill provides a minimum age of $11 \mathrm{Ma}$ for Thakkhola Graben (Coleman and Hodges, 1995; Garzione et al., 2000). Faults within the graben are observed to cut sediments as young as $11 \mathrm{Ka}$ (Hurtado et al., 2001). Fieldbased estimates for the total amount of displacement accommodated by the Dangardzang and Muktinath Faults range from 2-5 kilometers (Bordet et al., 1971; Colchen et al., 1986; Fort, 1996; Colchen, 1999; Hurtado et al., 2001). Colchen (1999) described a transpressional stress-regime in the northwest corner of the graben and attributed the complexity of faulting to interactions with the Karakoram Fault amid north-south shortening. In the north, Colchen et al. (1986) reported up to 4 kilometers of dip slip on the Dangardzang Fault, while in the south, Hurtado et al. (2001) found the Dangardzang transitions to dominantly dextral slip and potentially offsetting the brittle $\mathrm{AD}$ by as much as 3 kilometers. Hurtado et al. (2001) interpret the Dangardzang Fault as a tear fault accommodating variable displacement along the STDS. Thakkhola Graben may be associated with an along-strike shallowing of the MHT. Chamlagain and Hayashi (2005) note a change in the trend of microseismicity across Thakkhola Graben with events to the east emanating from a sub-horizontal MHT and events to the west appearing to emanate along a ramp in the MHT. Additionally, the southern end of the graben is close to the southeastern termination of the WNFS, which is proposed to be the surface expression of a ramp in the MHT (Fan and Murphy, 2021). Graben-related faulting could accommodate variable thickening between rocks to the west and east.
Researchers have associated extension in Thakkhola to other rifts and graben throughout the Tibetan plateau and Himalayan hinterland and an excellent summary is provided in (Garzione et al., 2003). Yin (2000) describes a southward increase in graben spacing from Tibet into Nepal, consistent with southward thickening of the crust. These structures accommodate extension parallel to the orogen, while north-south compression is accommodated on structures at the front of the Himalaya. Burchfiel and Royden (1985) and Dewey (1988) interpreted the STD to be an extensional structure. They associated extension along the STD and north-south trending rifts such as Thakkhola Graben to have resulted from excess gravitational potential energy accumulated during Oligocene crustal thickening. Alternatively, Himalayan rifts and graben could be accommodating differential orogen-parallel shear between regions of high and low obliquity with respect to the convergence direction (McCaffrey and Nabelek, 1998; Seeber and Pêcher, 1998), or they could accommodate differential stretching of the upper and lower crust as the Himalayan arc propagates southward (Jade et al., 2004; Copley and McKenzie, 2007; Murphy et al., 2009). The former predicts a decrease in orogen-parallel extension in central Nepal where the convergence direction is nearly perpendicular to the arc and the latter predicts nearly uniform orogen-parallel extension across the strike of the arc. Quantification of the magnitude of slip accommodated by the Dangardzang and Muktinath Faults is necessary for our understanding of east-west extension in the Himalayan Hinterland. To date the geometry of the graben-bounding faults is uncertain and existing models depict the Dangardzang Fault soling into the AD (Colchen, 1999; Hurtado et al., 2001). This is inconsistent with observations of crustal-scale folding of the STDS upper and lower plate (Searle and Godin, 2003; Fan and Murphy, 2021). Activity on the STDS, as currently described, should no longer be possible where the hanging wall and footwall are folded together. However, shear along an STD-like structure could continue within the wedge, probably near the rear at a structurally lower level. Determination of the depth of faulting within Thakkhola Graben will constrain the depth of decoupling between the upper and middle crust in the late Miocene.

\section{GEOLOGY OF THE THAKKHOLA GRABEN}

The Thakkhola Graben is bounded by two sets of steeply dipping, $\sim \mathrm{N} 20^{\circ} \mathrm{E}-\mathrm{N} 40^{\circ} \mathrm{E}$ striking normal faults: the Dangardzang Fault to the west and the Muktinath Fault to the east (Figs. 2 and 3). These faults are observed as far south as the crest of the High Himalaya, near the Annapurna Detachment. The Dangardzang Fault, the longest of the two faults, is traceable approximately 100 kilometers north to 


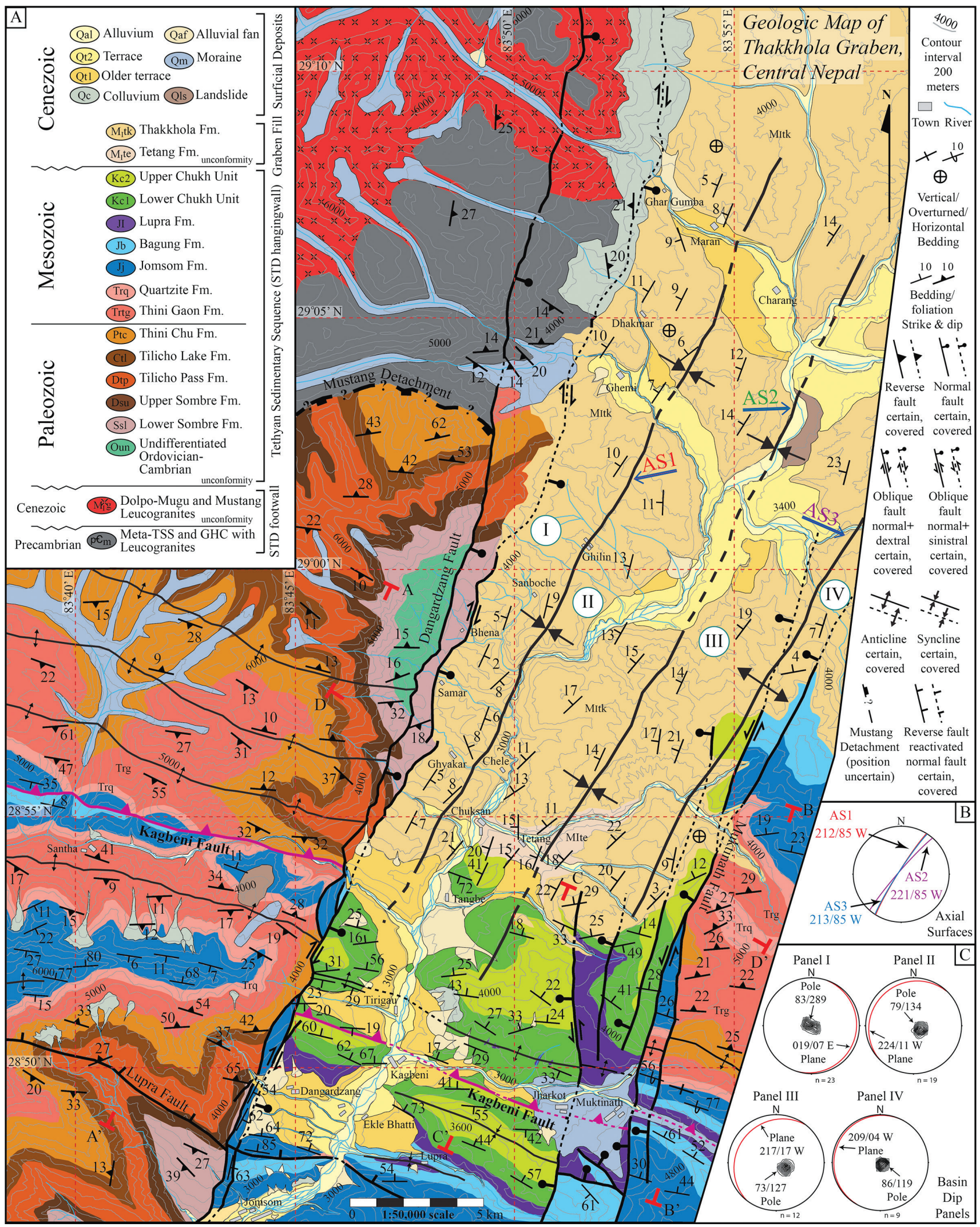

Fig. 3: (a) Geologic map of the Thakkhola Graben (1: 50,000 scale). Some regions were filled in with mapping by Colchen et al. (1981) and Godin et al. (2003). Refer to the text for details. Locations for cross-sections A-A', B-B', C-C', and D-D' are shown on the map. (b) Basin-fill folds (axial surfaces, AS1, AS2, AS3). Axial surfaces are interpreted to form due to slip over bends in the Dangardzang Fault surface; (c) Attitudes of dip panels in the hanging wall of the Dangardzang Fault. Locations are shown in 3a. Kagbeni Fault is shown in purple. 
the Indus-Yalu Suture while the Muktinath Fault is traceable for only 50-70 kilometers (Figs. 1 and 2). Additionally, two faults strike orthogonal to the trend of the graben; they are the Lupra Fault (Colchen et al., 1986; Godin, 2003) and a reverse fault we refer to as the Kagbeni Fault, (Fig. 2). Cross-section F-F' of Godin (2003) first depicts a central portion of this fault, therein referred to as the "Kagbeni Structure", in the cliffs immediately west of Kagbeni. Our field work reveals the presence of this structure across the graben and in both the Dangardzang Fault and Muktinath Fault footwalls. The Kagbeni Fault is offset by the Dangardzang and Muktinath Faults (purple fault in Fig. 3, and Fig. 4a). Therefore, it predates movement on both faults. The Lupra Fault extends from the western hanging wall of the graben into the middle of the basin. We did not observe it in the footwall of the Dangardzang Fault. However, Godin (2003) shows the Lupra fault to display a small amount of leftlateral separation across the Dangardzang Fault and is interpreted to be a reverse fault with later reactivation as normal fault.

Geologic field work was conducted at a 1:50,000 scale within the central portion of the graben over an area 50 kilometers north-south by 30 kilometers east-west (Fig. 3a). We also used Shuttle Radar Topography Mission (SRTM) digital elevation model and multispectral satellite images to constrain the geology of the northernmost portion of Thakkhola Graben. Through this effort we characterized the lithologies and structures of the basin and both footwalls. These geologic relationships are depicted in four crosssections: one in the footwall of the Dangardzang Fault (Fig. 5a), one in the footwall of the Muktinath Fault (Fig. 5b), one parallel to the basin (Fig. 5c), and one perpendicular to the basin (Fig. 5d).

\section{Dangardzang Fault Footwall}

The footwall of the Dangardzang Fault bounds the western side of the mapping area (Fig. 3a) and is represented in cross-section A-A' (Fig. 5a). In the southwest corner of the mapping area, west of the town of Jomsom, the Dangardzang footwall is composed of middle Paleozoic TSS folded into a north-vergent syncline cut by the east-west striking Lupra Fault. Here the Lupra Fault juxtaposes different portions of the aforementioned fold with minimal stratigraphic offset.

North of the Lupra Fault, middle Paleozoic through middle Mesozoic TSS make up the southern slope of Dangar ridge (Figs. 3a and 5a). The crest of this ridge is composed of the Jurassic Jomsom Formation folded into a tight, north-vergent anticline-syncline pair with an axial plane attitude of 097/13 S. The Jomsom Formation comprises the ridge crest as well as a portion of the northern slope down to about 4000 meters. Toward the valley the Quartzite and Thini Gaon Formations are exposed in a north-vergent anticline with an almost 90o interlimb angle and an axial plane attitude of $\sim \mathrm{N} 65^{\circ} \mathrm{W}, 50^{\circ} \mathrm{SW}$ (Fig 3a and 5a). Down slope and towards Santha village the dip shallows from $\sim 30-40^{\circ} \mathrm{NE}$ to $\sim 10^{\circ} \mathrm{NE}$ as the rocks are more broadly folded (Fig. 5a). The Bagung Formation is exposed in the cliffs just north of Santha marking the youngest TSS rocks in the Dangardzang Fault footwall. Here the Kagbeni Fault is observed as a steeply dipping and $295^{\circ}$ striking reverse-sense fault outcrops north of Santha. East of Santha the trace of the fault extends downhill towards the valley and to the west it trends uphill (Fig. 3a). The Kagbeni Fault is top-to-the-south and accommodates 500-700 meters of vertical separation (Fig. 5a). In the Dangardzang footwall this fault is a structural boundary separating north-vergent to upright folding in the south from south-vergent folding in the north (Fig. 5a). On the basis of fault plane geometry and comparable structural relationships, we interpret this fault to be a western continuation of the reverse-sense shear zone depicted in the "Kagbeni Structure" of Godin (2003). The trace of the Kagbeni Fault is cut and offset along the Dangardzang Fault with $\sim 6.5$ kilometers of right-lateral separation (Fig. 3a). The slope north of Santha exposes the Thini Chu and Thini Gaon Formations folded multiple times into several upright to slightly south-vergent syncline-anticline pairs. The southernmost of these, at 4000 meters elevation in cross-section $\mathrm{A}^{-} \mathrm{A}^{\prime}$, has an interlimb angle approximately $100^{\circ}$ while the other folds are approximately $120-140^{\circ}$ (Fig. 5a). The deepest TSS rocks exposed in the mapping area are found west of the villages of Samar and Bhena (Fig. 3a). This section is mapped as undifferentiated Cambrian-Ordovician, most likely the Nilgiri Formation, consisting of lowgrade, blue-gray marble and fine-grained sandstone. North of the $29^{\circ} 00^{\prime} \mathrm{N}$ line and at approximately 5400 meters elevation a major structural and metamorphic discontinuity has been recognized. Above this discontinuity are unmetamorphosed middle-late Paleozoic TSS and below this discontinuity are metamorphic rocks interpreted to be part of the GHC. The metamorphic rocks consist of garnet-staurolite schist, biotite schist, garnet-biotite schist, and calcsilicate gneiss all pervasively intruded by leucogranite dikes and sills. Across the metamorphic discontinuity is a change from folded TSS above to shallowly dipping $\left(>30^{\circ}\right)$, nearly homoclinal metamorphic rocks (Fig. 3a). This discontinuity is herein referred to as the Mustang Detachment and it appears to be similar in style and structural position to the Phu Detachment (Searle and Godin, 2003) (Fig. 2). The TSS is truncated against the Mustang Detachment, implying a ramp relationship with the fault (Fig. 3a). Direct observation of the detachment surface was not possible; therefore its position is approximate. The northwest corner of the 
mapping area in Fig. 3a is composed of leucogranite intruding metamorphosed Cambrian-Ordovician TSS or the uppermost formations of the GHC. These leucogranites have been described by previous authors as consisting of two granitic bodies; the Dolpo-Mugu and the Mustang leucogranites (Colchen et al., 1986; Le Fort and France-Lanord, 1995; Harrison et al., 1999; Hurtado et al., 2001). Previous authors place the boundary between the Dolpo-Mugu and Mustang leucogranites along the northwest-trending valley running through the villages of Charang and Maran (Colchen et al., 1986; Hurtado et al., 2001). Our field mapping, combined with analysis of ASTER data and Google Earth imagery, reveals no clear boundary between these granites (Fig. 3a). Accordingly, we have mapped this as a continuous leucogranite pluton, with the Mustang leucogranite being a north-trending arm of the much larger east-west trending Dolpo-Mugu leucogranite (Fig. 2). The footwall of the Dangardzang Fault at the northern boundary of Fig. 3a is composed of leucogranite capped by a few hundred meters of calcareous schist and garnet-biotite gneiss. The trace of the Dangardzang Fault can be followed until it runs into a 10 kilometer wide, northwest-trending valley at $\sim 30^{\circ} \mathrm{N}$.

\section{Muktinath Fault Footwall}

The footwall of the Muktinath Fault, represented in cross-section B-B', comprises the southeast corner of the mapping area near the town of Muktinath (Figs. $3 a$ and $4 a$ ). East of Muktinath, the peaks of Thorung North and Thorung South are composed of Mesozoic TSS folded into two kilometer-scale anticlines with a tight syncline in the intervening valley (Figs. 3a, 4a, and 5b) (Colchen, 1981). The southeastern portion of Fig. 3a includes the northern slope of Thorung South. This slope is the northern limb of a slightly south-vergent anticline with an axial plane attitude of 293/85 N (Fig. 4a). Close to the peak the northern limb of the Thorung South anticline is composed of the Jomsom Formation and the younger Bagung and Lupra Formations exposed in regular stratigraphic succession towards the valley (Figs. $3 \mathrm{a}$ and $5 \mathrm{~b}$ ). Thorung La valley is composed of the Lupra Formation and surrounded by steeply dipping Bagung Formation rocks on the valley walls (Figs. $3 \mathrm{a}$ and $5 \mathrm{~b}$ ). The Tethyan rocks within the valley are folded into a south-vergent isoclinal syncline cut by a steeply north-dipping, reverse-sense fault (Fig. 5b). On the basis of the fault plane attitude as well as its position relative to surrounding folds we interpret this fault to be the eastward continuation of the Kagbeni Fault observed in the Dangardzang Fault footwall. The top-to-the-south Kagbeni Fault strikes $\sim 300^{\circ}$ and runs parallel to Thorung La Valley where it is buried by glacial deposits (Figs. 3a and 4a). Thorung North is composed of the Lupra through Jomsom sequence
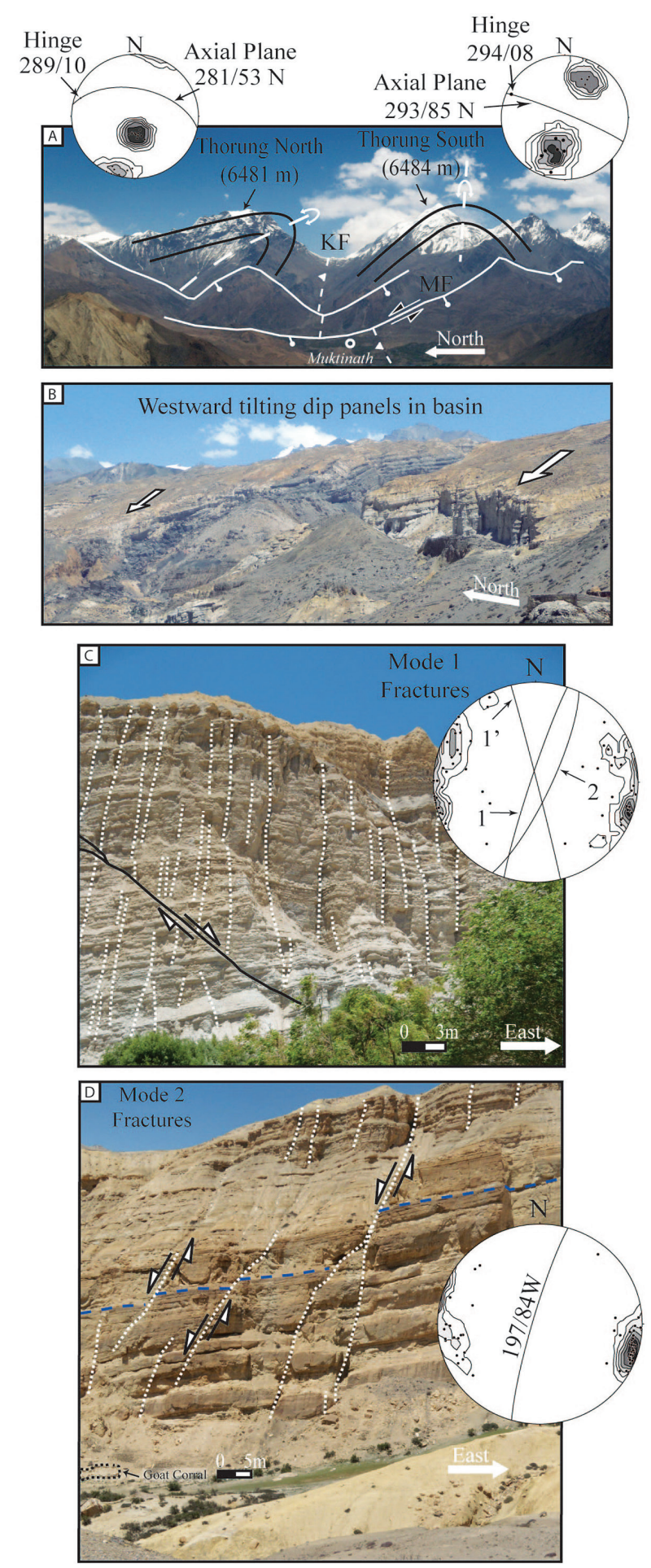

Fig. 4: (a) View of Thorung North/South folds, with Kagbeni and Muktinath Faults, near the town of Muktinath. (b) View within the Thakkhola Graben basin showing dip panels in the basin-fill formations. (c) View of mode-1 fractures within the Thakkhola Graben basin. Inset stereonet shows 54 mode-1 fractures in 3 sets: Set 1 is oriented 198/86 W; Set 1 ' is oriented 351/90; Set 2 is oriented 026/79 E. Sets 1 and 1' are interpreted to be associated with graben-related deformation. Set 2 is the least abundant and the orientation implies a relationship with pre-existing TSS deformation. (d) View of mode-1/mode-2 fractures and small faults within the Thakkhola Graben basin. Inset stereonet shows the orientation of mode- 2 fractures. 


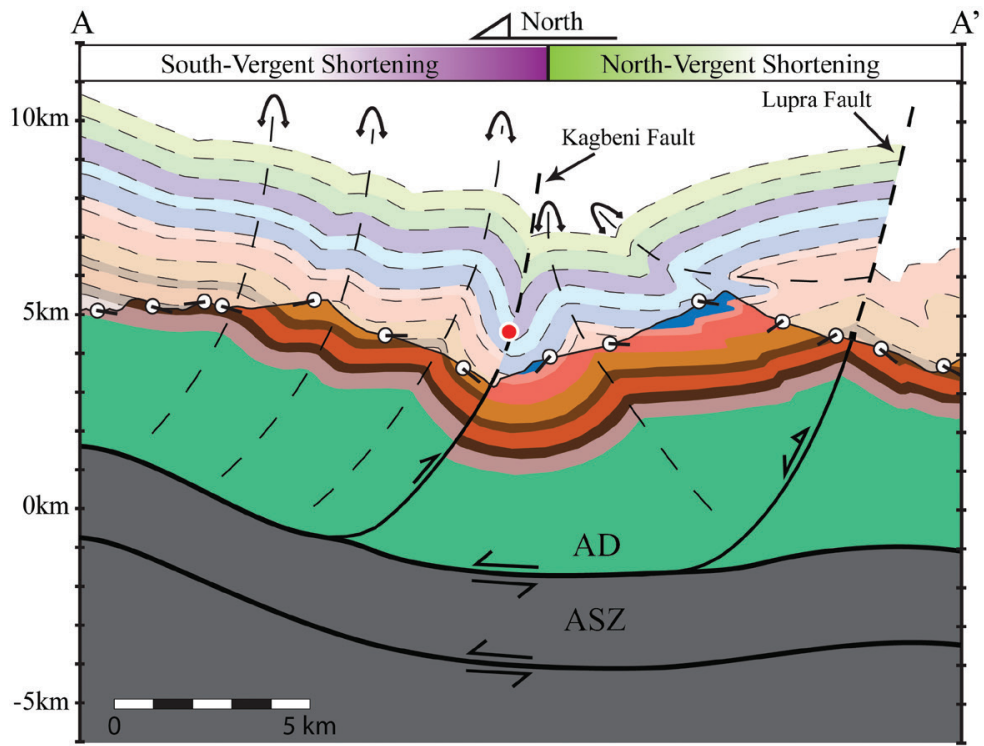

(a)

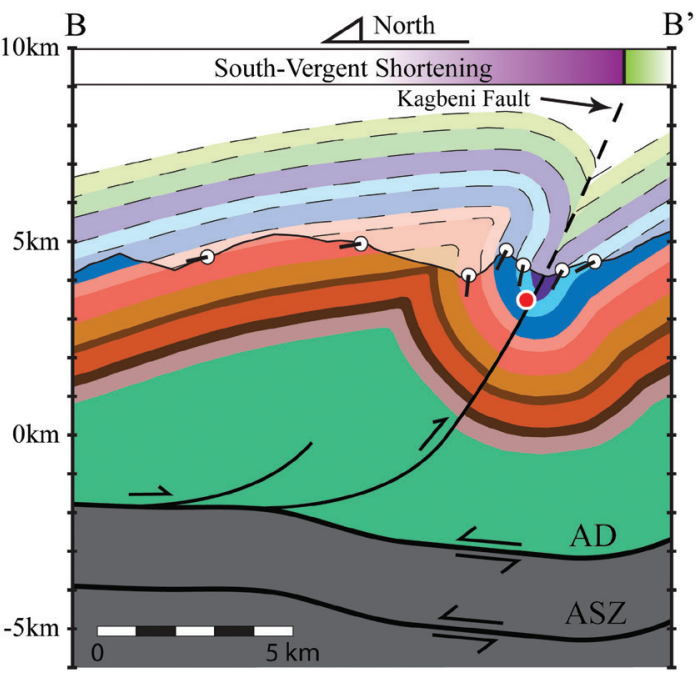

(b)

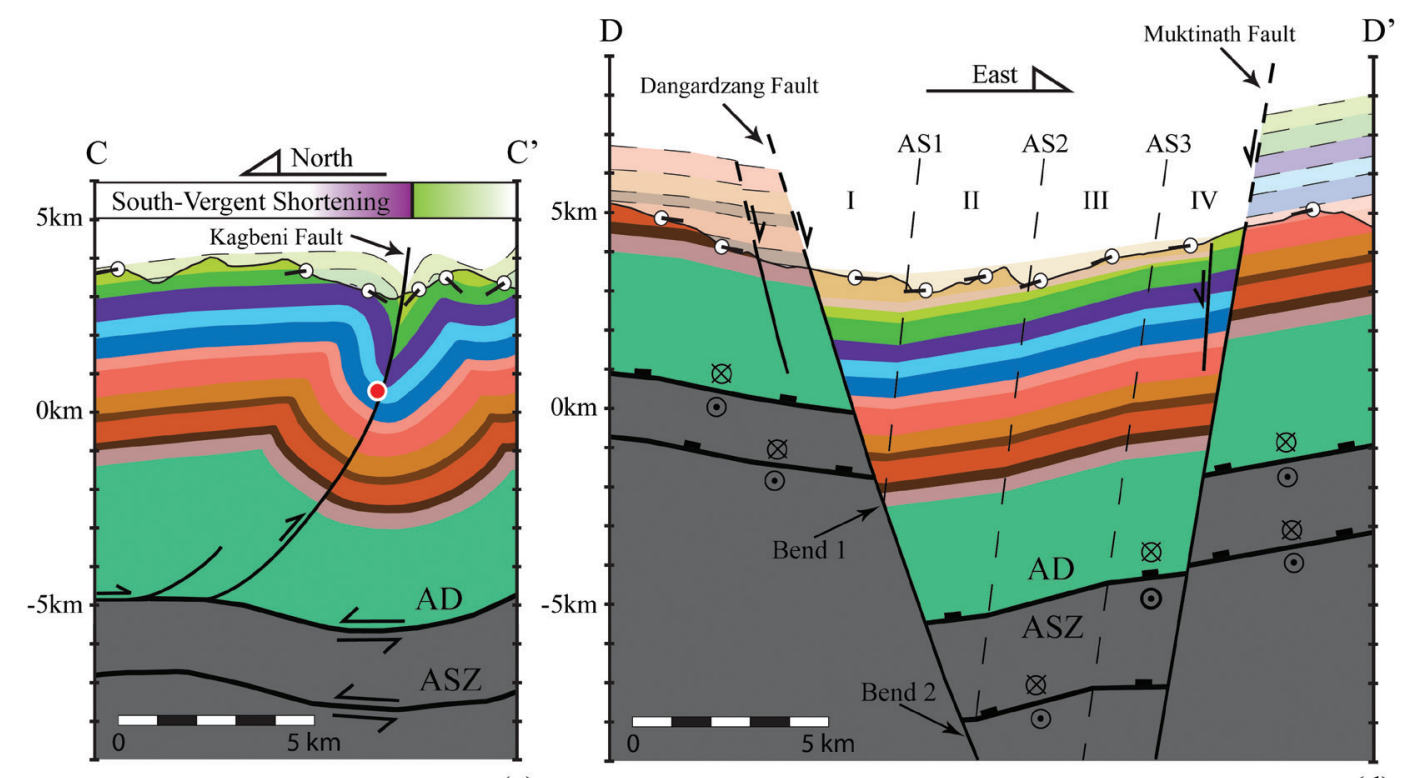

(c)

Fig. 5: (a) Cross-section A-A' in Dangardzang Fault footwall crossing Kagbeni Fault; (b) Cross-section B-B' in Muktinath Fault footwall crossing Kagbeni Fault; (c) Cross-section C-C' within Thakkhola Graben crossing Kagbeni Fault; (d) Cross-section D-D' perpendicular to Thakkhola Graben crossing Dangardzang Fault and Muktinath Fault. Two slight bends are interpreted along the Dangardzang Fault. These bends are associated with the dip panels, I, II, III, and IV, observed in the basin. Red circle in A, B, and C delineates the piercing line used in our slip calculation.

which is overturned and steeply dipping in the southern limb of the Thorung North anticline (Figs. 3a and $5 \mathrm{~b}$ ). The Thorung North anticline is south-vergent with an axial plane attitude of 281/53 N (Fig. 4a). The trace of the axial plane appears to be offset along the Muktinath Fault with sinistral separation. Consistent with observations in the Dangardzang Fault footwall, the Kagbeni Fault is a structural boundary separating south-vergent folds in the north from north-vergent or upright folds in the south (Figs. $4 \mathrm{a}$ and $5 \mathrm{~b}$ ). The northernmost portion of the Muktinath Fault footwall is buried by the Thakkhola Formation.

\section{Tethyan Fold Interpretation}

Within our field area fold orientations change from north-vergent to upright or south-vergent from the southern to north across the Kagbeni Fault. Northvergent folds observed on Dangarz and Tasartse peaks are associated with the $\mathrm{D}_{2}$ phase of deformation. Upright folds such as the one comprising Thorung South may have initially been north-vergent and reoriented during $\mathrm{D}_{4}$ south-vergent compression. South-vergent folds such as the Thorung North anticline and those others found north of the Kagbeni 
Fault are associated with the $\mathrm{D}_{4}$ south-vergent compressional phase of deformation. The transition from north- to south-vergent folds suggests the intensity of $\mathrm{D}_{2}$ north-vergent back folding diminishes towards the north allowing $\mathrm{D}_{2}$ folds in the northern portion of the mapping area to be reoriented during $\mathrm{D}_{4}$. No $\mathrm{D}_{2}$ structures are observed north of the Kagbeni Fault. The transition from north- to southvergent folds is regionally continuous and marked by a steeply dipping reverse fault which, according to cross-cutting relationships, must pre-date Thakkhola Graben. This transition of fold vergence defines the axis of a syncline which we interpret to be the upper crustal expression of the Dolpo-Mugu-Manang synclinorium (Figs. 2 and $5 a$ ).

\section{Thakkhola Graben Basin}

Thakkhola Graben is bounded to the east and west by the Muktinath and Dangardzang Faults, respectively (Figs. 3a and 5d). The width of the graben varies from $\sim 5$ kilometers around the Annapurna Detachment in the south to as much as 25-30 kilometers at the NepalTibet border in the north (Colchen, 1999; Godin, 2003). The graben-bounding faults continue as far south as the Annapurna Detachment (Brown and Nazarchuk, 1993; Godin et al., 1999; Godin, 2003), but thick accumulation of basin-fill sediment is restricted to the region north of the Lupra Fault (Fig. 3a). The northern boundary of the basin is less well-defined owing to accessibility issues near the Tibet-Nepal border. Analysis of SRTM elevation data coupled with Aster multispectral imagery facilitated mapping of the northernmost segments of the Dangardzang Fault and the adjacent basin. The northern margin of the graben roughly coincides with the Dolpo-MuguManang anticlinorium (Cannon and Murphy, 2014) (Fig. 2). Here, displacement on the Muktinath Fault diminishes and the Dangardzang Fault continues north for another 15-30 kilometers.

The southernmost portion of our geologic map (Fig. 3a), around Jomsom and Kagbeni, is adapted from mapping by Godin (2003). In this portion of the map, east-west trending, kilometer-scale folds in the TSS produce the ridges surrounding the towns of Jomsom and Lupra. The rocks exposed here are, from south to north, early Jurassic through upper Cretaceous TSS with a small outcrop of the upper Triassic Quartzite Formation at the intersection of the Lupra Fault with the Kali Gandaki River (Fig. 3a). These rocks are folded into a syncline with an axial plane attitude of 097/ 80 S (Figs. 3a and 5c). The Kagbeni Fault crops out in the ridges surrounding the town of Kagbeni. West of Kagbeni, this fault juxtaposes Lower Chukh Formation rocks in its hanging wall against Upper Chukh Formation rocks in its footwall; to the east it juxtaposes two units of the Upper Chukh Formation, the Dzong Unit in the hanging wall against the Muding Unit in the footwall. Near Muktinath the Kagbeni Fault is poorly exposed due to a thick accumulation of glacial sediment (Fig. 4a). One compatible fault surface was found within the Lupra Formation shale between the towns of Jharkot and Muktinath (Fig. 3a). North of the Kagbeni Fault the Chukh Formation rocks are folded into a moderately south-vergent anticline with an axial plane attitude of $281 / 79 \mathrm{~S}$. We interpret this to be an offset continuation of the south-vergent Thorung North anticline in the Muktinath Fault footwall and the south-vergent anticline observed north of the Kagbeni Fault in the Dangardzang footwall (Figs. 3a, 5a, 5b, and 5c). The anticline observed in the valley represents a structurally higher and 260 steeper portion of the anticline observed in the adjacent footwalls.

North of Chuksan and Tetang the basin-fill formations are in buttress unconformity with the underlying folded TSS. In general, the Tetang and Thakkhola Formations dip west towards the Dangardzang Fault (Fig. 4b) with dip decreasing with increasing distance from the fault (Figs. 3a, 3c, and 5d). We group the attitudes of the basin fill into four dip panels consisting of, from west to east: Panel I dipping $7^{\circ} \mathrm{E}$, Panel II dipping $11^{\circ} \mathrm{W}$, Panel III dipping $17^{\circ} \mathrm{W}$, and Panel IV dipping less than $4^{\circ} \mathrm{W}$ (Figs. 3a, 3c, and 5d). These dip panels are observable as far south as Tangbe village and have been mapped as far north as the villages of Maran and Charang (Fig. 3a). Panel I borders the Dangardzang Fault on the western side of the basin and extends 3-5 kilometers to the east (Figs. 3a and 3c). The rocks exposed within this dip panel belong to the Thakkhola Formation and generally dip $7^{\circ} \mathrm{E}$ away from the Dangardzang Fault. Panel II is $\sim 4.5$ kilometers wide and is $\sim 5$ kilometers west of the Dangardzang Fault. Panel II is observable in the inclined Thakkhola and Tetang Formations surrounding the villages of Chuksan and Tetang. This panel dips on average $11^{\circ} \mathrm{W}$ with dips up to $20^{\circ} \mathrm{W}$ in the Tetang Formation; the range of dips is due to the angular unconformity between the basin-fill formations. Panel III is $\sim 4$ kilometers wide and composed of the Thakkhola Formation with a portion of Tetang Formation exposed on the western side. This panel dips an average of $17^{\circ} \mathrm{W}$ with dips in the Thakkhola Formation up to $23^{\circ} \mathrm{W}$. Panel IV borders the Muktinath Fault on the eastern side of the graben and is composed of rocks of the Thakkhola Formation. This panel is essentially horizontal with dips up to $4^{\circ} \mathrm{W}$. These four regionally extensive dip panels are separated by three axial surfaces labeled, from west to east: AS1, AS2, and AS3 (Figs. 3a and $3 b)$. These axial surfaces parallel the Dangardzang Fault and are continuous for at least 50 kilometers. Their strikes are determined by bisecting the average strikes of adjacent dip panels. AS1 separates Panel I 
and Panel II and strikes $212^{\circ}$; AS2 separates Panel II and Panel III and strikes 221 $1^{\circ}$; AS3 separates Panel III and Panel IV and strikes $213^{\circ}$. The dip of the axial surfaces is $\sim 85^{\circ} \mathrm{W}$ (Fig. 3b).

Fifty-seven mode- 1 and fifty-four mode- 2 fracture measurements were collected from the Thakkhola and Tetang Formations. Three concentrations of fractures have been observed: set 1 oriented at 198/86 W, set 1' oriented at 351/90, and set 2 oriented at 026/79 E (Fig. $4 c)$. Set 1 and 1 ' are the dominant orientations of the mode- 1 basin fractures. Sets 1 and 2 are sub-parallel to the Dangardzang and Muktinath Faults and set 1' is $\sim 30^{\circ}$ oblique to them. Mode- 2 fractures within the basin typically have offsets on the order of a few centimeters with some having coalesced into steeply west-dipping intraformational faults with offsets of a few meters (Fig. 4d). Shear along these fractures is west-side-down towards the Dangardzang Fault.

\section{Interpretation of Basin Fill Folds}

Based on (1) the trend of the dip panels paralleling the Dangardzang Fault and (2) the large scale of these dip panels suggesting a deeply rooted cause, we interpret the variation in panel attitudes to be attributed to inclined normal shear imposed on the hanging wall as it moves over slight bends in the Dangardzang Fault surface (Fig. 5d). This fault surface becomes slightly shallower at depth. Extensional fault-bendfolding predicts that slip over a bend with a shallower fault dip causes tilting of the hanging wall to towards the fault and slip over a bend with a greater fault dip causes the hanging wall to tilt away from the main fault (Xiao and Suppe, 1992). Adjacent dip panels are separated by an axial surface that is tied to the fault bend at an angle parallel to the angle of inclined shear. A dip angle of $85^{\circ} \mathrm{W}$ has been determined through observation of steeply-dipping, low displacement fractures within the basin fill, we estimate these axial surfaces strike $212-221^{\circ}$ and dip $85^{\circ} \mathrm{W}$ (Figs. $3 b, 4 c$, and 4d). The increase in dip from Panel I to Panel II and from Panel II to Panel III is interpreted to be the result of a slight decrease in the dip of the Dangardzang Fault occurring where AS1 and AS2 root into the fault surface (Fig. 5d). AS1 and AS2 are active axial surfaces, separating rocks that have not yet passed over their respective bends from those that have; as such they are tied to the bends in the fault surface and do not move with displacement. The horizontal Panel IV represents rocks that never passed over a bend in the fault. These rocks were originally down-dip of the bend at AS2 and have only passed over a fault surface with constant dip so they retain their original orientation. AS3 is therefore interpreted to be a passive axial surface that initiated at AS2 and moved with the hanging wall with each increment of slip. The passive axial surface associated with AS1 has been translated through the bend at AS2 and it is no longer observable.

\section{Dangardzang Fault}

The Dangardzang Fault bounds the western side of Thakkhola Graben from the Dhaulagiri range in the south to the Indus Yalu Suture in the north (Bordet et al., 1971; Colchen, 1981) (Fig. 1). We have mapped the Dangardzang Fault north of Kagbeni for $\sim 100$ kilometers. Fig. 3a depicts 40 kilometers of the Dangardzang Fault determined through field mapping; the Jomsom-Kagbeni area is adapted from Godin (2003). The Dangardzang Fault consists of two parallel faults over the majority of its length. In the south the faults are separated by only a few hundred meters with both strands facilitating a few thousand meters of stratigraphic separation (Fig. 3a). West of Kagbeni the fault strands merge for $\sim 2$ kilometers until the valley leading to Santha village where the western strand appears again (Fig. 6a). Stratigraphic separation is very low, around 200 meters, for this portion of the western fault. Moving northward the fault strands diverge to $\sim 2.5-3$ kilometers and separation on the western fault increases to about 1 kilometer (Fig. 3a). In southern Tibet the easternmost Dangardzang Fault is expressed through dextral offset of several ridges and streams immediately adjacent to the basin. The westernmost fault is expressed as a linear arrangement of small fault scarps. The northern termination of the Dangardzang Fault is unclear, but it can be traced as far as $29^{\circ} 45^{\prime} \mathrm{N}$.

A bend in the surface trace of the Dangardzang Fault appears near the Tibet-Nepal border. South of the border the fault strikes between $025^{\circ}$ and $035^{\circ}$; north of the border it strikes $000^{\circ}$ to $010^{\circ}$. In crosssectional view there are two slight bends in the surface of the easternmost Dangardzang Fault, Bend 1 at 2 kilometers below sea level and Bend 2 at 8 kilometers below sea level (Fig. 5d). At the surface the fault dips $74^{\circ} \mathrm{E}$, then $70^{\circ} \mathrm{E}$ below Bend 1 , and $67^{\circ} \mathrm{E}$ below Bend 2. The Dangardzang Fault is interpreted to cut down to at least 10 kilometers below sea level. This fault bend geometry was determined by forward modeling of the hanging wall deformation over trial fault surfaces using Midland Valley's 2DMove. Three concentrations of fault striae are measured on the Dangardzang Fault: set 1 oriented at 62/094; set 1' at 86/198; and set 2 at 18/194 (Fig. 6b). Set 1 and 1 ' were equally abundant and both indicative of dipslip motion. Set 2 was less abundant than 1 and $1^{\prime}$ and was indicative of dominantly dextral strike-slipoblique motion. Several fault surfaces show dip-slip striae (in blue) overprinting strike-slip striae (in red) as is depicted in stereoplot A2 (Fig. 6a). This implies the western boundary of Thakkhola Graben initiated as a dextral-oblique-slip fault and evolved into a dip-slip fault. No clear cross-cutting relationship exists between the western and eastern fault 


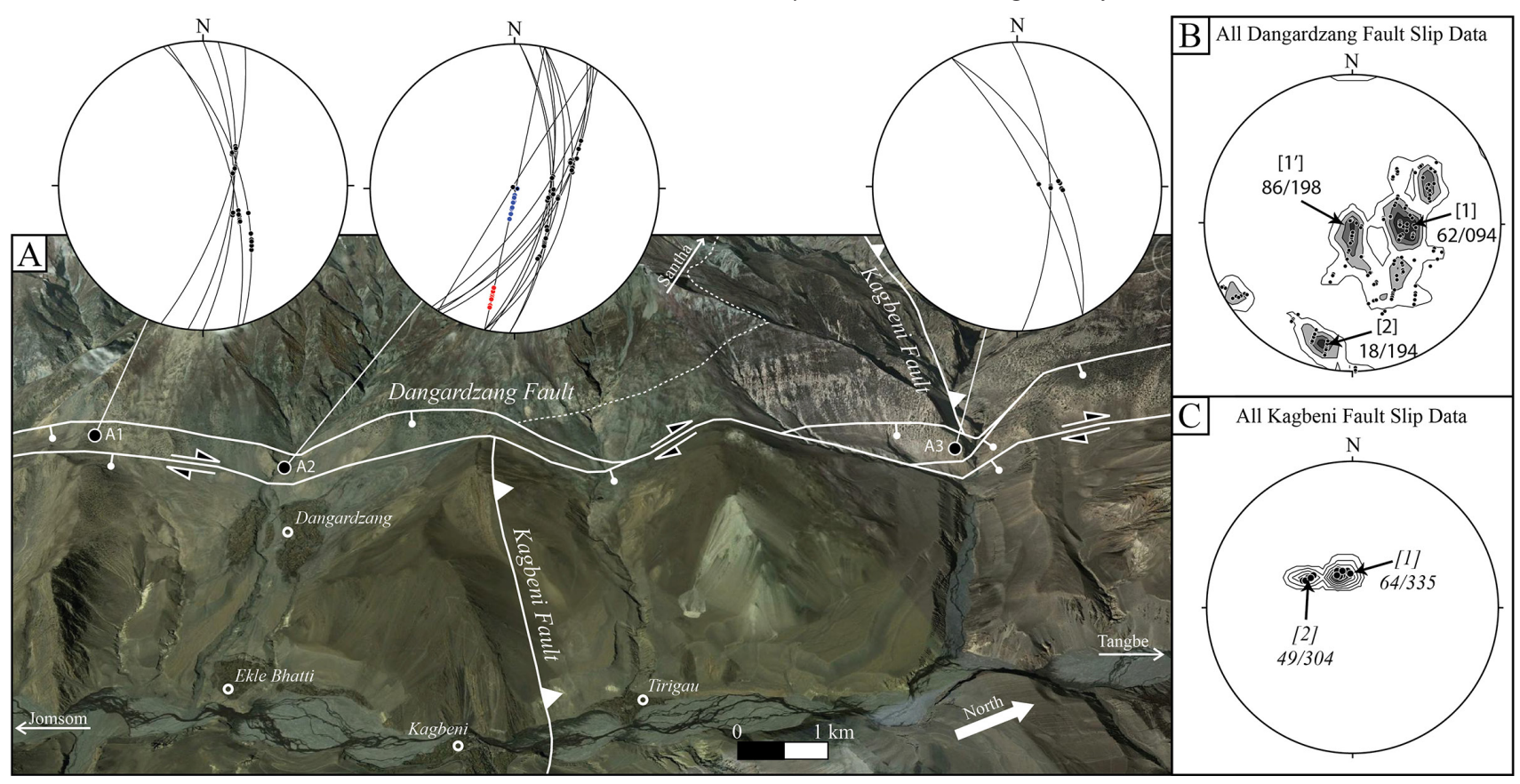

Fig. 6: (a) Google Earth image showing the Dangardzang and Kagbeni Faults near town of Kagbeni. Here the Kagbeni Fault is offset along the Dangardzang Fault with right-lateral separation. Inset stereonets show orientation and sampling locations, A1, A2, and A3, for a portion of Dangardzang Fault data. These show two sets of striae, oblique and dip-slip. At location A2 dip-slip striae (blue) overprint (oblique-slip striae (red). (b) Stereonet of 181 Dangardzang Fault striae. Data show 3 sets: Set 1 oriented at 62/094; Set 1 ' at 86/198; and Set 2 at 18/194. Dominant orientation is dip-slip. (c) Stereonet of 72 Muktinath Fault striae shows 2 sets: Set 1 oriented at 22/199; Set 2 at 73/225, both of which are dip-slip.

strands.

\section{Muktinath Fault}

The Muktinath Fault bounds the eastern side of Thakkhola Graben and is composed of a series of subparallel faults that have been mapped as far south as the Annapurna range and into southern Tibet where their termination is not clearly defined (Bordet et al., 1971; Colchen, 1981) (Fig. 2). We mapped this set of faults for $\sim 30$ kilometers from the western slopes of Thorung South to the mountains east of Tetang village (Figs. 3a and $4 \mathrm{a}$ ). In the southwestern portion of the mapping area these faults cut through Jurassic Tethyan carbonate rocks, facilitating exhumation of the peaks of Thorung North and South. Here the two easternmost strands of the Muktinath Fault have offset the overturned limb of the Thorung North anticline and the Kagbeni Fault (Fig. 4a). The horst block is a structurally higher portion of the fold seen in the background footwall. These two strands of the Muktinath Fault converge and share a common trace for a few kilometers before diverging again. There is no clear cross-cutting relationship between these two fault traces (Fig. 3a). Two shorter faults, 5-10 kilometers long, are mapped north of Muktinath town where they cut the Cretaceous TSS. The westernmost of these, running between Jharkot and Muktinath, is continuous for $\sim 10-15$ kilometers in the mapping area and is observed to the south for some 10's of kilometers (Godin, 2003). The northern extent of the Muktinath Fault is difficult to trace to the north due to thick accumulations of basin fill and inaccessibility around the Tibet-Nepal border.

These fault traces display two common orientations: one set is oriented $\sim 000-010^{\circ}$; the other set oriented $\sim$ $030-045^{\circ}$ (Fig. 3a). The transition between these two sets is gradual and occurs east of Tangbe village. The faults making up the eastern boundary of Thakkhola Graben dip steeply to the west at $80-90^{\circ}$ and, based on the deepest unit observed to be offset at the surface, are interpreted to cut down to at least 5 kilometers below sea level (Fig. 5d). Two sub-equal concentrations of fault striae have been found on these faults: set 1 oriented at 22/199; set 2 at 73/225. Set 1 is oblique with a dominantly sinistral strike-slip component and set 2 is almost pure dip-slip. The strike-slip striae are overprinted by dip-slip striae. The easternmost faults appear to have accommodated the highest magnitude of strain with a stratigraphic separation of $\sim 3.5$ kilometers while the westernmost fault shows 1 kilometer of stratigraphic separation (Figs. 3a and 5d). The shorter length faults have separations of less than 1 kilometer. The eastern boundary of Thakkhola Graben appears to have formed in two phases, characterized by sinistral strike-slip faulting followed by normal faulting. Cross-cutting relationships are unclear, but faulting appears to step basin-ward and towards the south with time (Fig. 3a). 


\section{Kagbeni Fault}

The Kagbeni Fault extends east-west across the mapping area and consists of three segments separated by the graben-bounding faults. These segments are correlated on the basis of geometry, kinematics, and structural position. The Kagbeni Fault crops out in the Dangardzang Fault footwall near the village of Santha, in the Muktinath Fault footwall along Thorung La valley, and within the graben near the towns of Muktinath and Kagbeni (Figs. 3a, 4a, and 6a). The central segment of this fault is likely associated with the "Kagbeni structure" depicted in cross-section F-F' of Godin (2003). Our field mapping shows 5-6 kilometers of separation with apparent right-lateral sense between the western and central segments along the Dangardzang Fault (Figs. 3a and $6 \mathrm{a}$ ). The central and eastern segments show 1 kilometer left-lateral separation along the Muktinath Fault (Figs. 3a and 4a). Four fault surfaces were found with strikes ranging from $254-285^{\circ}$ and dips ranging from $58-65^{\circ} \mathrm{N}$. There are two concentrations of dipslip striations on the fault surfaces: set 1 is oriented 64/335 and set 2 is oriented 49/304 (Fig. 6c). These kinematic data for the Kagbeni Fault are compatible with the D4 south-verging compressional phase of deformation for the TSS (Godin, 2003). No direct observation of any offset within the GHC was made and therefore we conservatively interpret the Kagbeni Fault to shallow at depth where it soles into the upper Annapurna Detachment. Along its length the Kagbeni Fault juxtaposes a south-verging anticline in its hanging wall and an upright to north-verging anticline in its footwall. The coincidence of a reverse fault in the core of a synformal transition of fold vergence is compatible with regional observations of crustal-scale folding. We interpret the Kagbeni Fault to be located along the axis of a syncline comparable to the DolpoMugu-Manang synclinorium (Searle and Godin, 2003; Cannon and Murphy, 2014) (Figs. 2, 3a, 5a, 5b, and $5 \mathrm{c})$.

\section{Mustang Detachment}

The Dangardzang footwall to the west of the village of Ghemi contains a previously unrecognized structural and metamorphic discontinuity herein referred to as the Mustang Detachment although no direct observation of the detachment was possible due to lack of accessibility (Figs. 2 and 3a). The Mustang Detachment separates unmetamorphosed TSS in the hanging wall and metamorphosed lowermost TSS or GHC in the footwall. The immediate hanging wall rocks are the Carboniferous through Triassic marine sedimentary rocks of the TSS. In the immediate footwall of the Mustang Detachment there is a sharp increase in metamorphic grade. These rocks consist of quartzites, marbles, garnet-staurolite schists, and calcsilicate gneisses, consistent with lowermost TSS or, more likely, the uppermost GHC. The footwall rocks have been pervasively intruded by leucogranite, sills, and dikes. These leucogranites cross-cut the dominant foliation and are themselves sheared, suggesting that they intruded contemporaneously with the country rock deformation. Unfortunately, aaccessibility issues precluded structural measurements in this area.

The leucogranite bodies most likely emanate from the Dolpo-Mugu and Mustang leucogranites (Figs. 2 and 3a). The detachment represents a structural discontinuity between the macroscopically folded TSS above and the nearly homoclinal foliation found in the metamorphic rocks below. More work remains in order to ascertain the position and kinematics of this detachment; however our observations suggest a comparison to the Phu Detachment in the Manaslu region east of Thakkhola Graben and the Annapurna Detachment to the south (Fig. 2) (Searle and Godin, 2003). These three detachments are similar in structural and lithological boundaries, leading us to assert that the Mustang Detachment is the northern continuation of the brittle contact at the structurally highest level of the STDS in central Nepal (Caby et al., 1983; Burchfiel et al., 1992; Brown and Nazarchuk, 1993; Godin et al., 1999; Godin, 2003). This also implies the Dolpo-Mugu and Mustang leucogranites belong to the Higher Himalayan granite belt (Debon et al., 1981; Le Fort, 1981; Debon et al., 1984; Schärer et al., 1986; Le Fort et al., 1987; Harrison et al., 1997). The STDS daylights in the Thakkhola region because it is folded within the Dolpo-Mugu anticlinorium-synclinorium in the same way that it is folded within the Manang anticlinorium-synclinorium in the Marsayandi valley (Searle and Godin, 2003; Fan and Murphy, 2021).

\section{MAGNITUDE OF SLIP ALONG GRABEN FAULTS}

The magnitude of slip accommodated by the Dangardzang and Muktinath Faults is evaluated through the analysis of common piercing points found on adjacent sides of the graben-bounding faults. The intersection of the Bagung-Jomsom Formation contact with the surface of the Kagbeni Fault defines a suitable piercing line that can be located in the hanging wall and both footwalls of Thakkhola Graben (Figs. 5a, 5b, and $5 \mathrm{c}$ ). Block models were made by aligning the long axis of a rectangular prism with the strike direction for the Dangardzang and Muktinath Faults (Figs. 7a and $7 \mathrm{c}$, respectively). The geometry of the Kagbeni Fault as well the position of the Bagung-Jomsom Formation contact on the hanging wall side of the Kagbeni Fault are projected into the block models. These contacts are positioned in order to represent their respective three-dimensional orientation in the hanging wall and footwall of the basin-bounding fault to be analyzed. In each model the piercing lines intersect the basinbounding faults and define a slip vector which we use 
to evaluate the net slip magnitude, net slip direction, dip-slip displacement, strike-slip displacement, and magnitude of horizontal extension (Figs. $7 b$ and $7 d$ ).

The slip model for the Dangardzang Fault is represented in Figs. $7 \mathrm{a}$ and $7 \mathrm{~b}$. The block diagram is oriented parallel to the strike of the Dangardzang Fault (018) (Fig. 7a). This calculation results in a slip vector of magnitude 7.1 kilometers, plunging $39^{\circ}$ in the direction $185^{\circ}$ (Fig. $7 \mathrm{~b}$ ). The piercing points have been displaced with a right-lateral normal-oblique sense by 4.5 kilometers in the dip-slip direction, 5.3 kilometers in the strike-slip direction, with 1.4 kilometers of horizontal extension (Fig. 7b).
The slip model for the Muktinath Fault is represented in Fig. 7c with Fig. 7d representing the slip vector. The block diagram is oriented parallel to the strike of the Muktinath Fault (018) (Fig. 7c). The slip vector shows a magnitude of 4.7 kilometers, plunging $65^{\circ}$ in the direction $218^{\circ}$ (Fig. $7 \mathrm{~d}$ ). The piercing points are displaced with a left-lateral normal-oblique sense by 4.2 kilometers in the dip-slip direction, 1.9 kilometers in the strike-slip direction, with 0.8 kilometers of horizontal extension (Fig. 7c).

It is uncertain whether these are maximum or minimum slip estimates. The Dangardzang Fault is traceable for approximately 100 kilometers north of

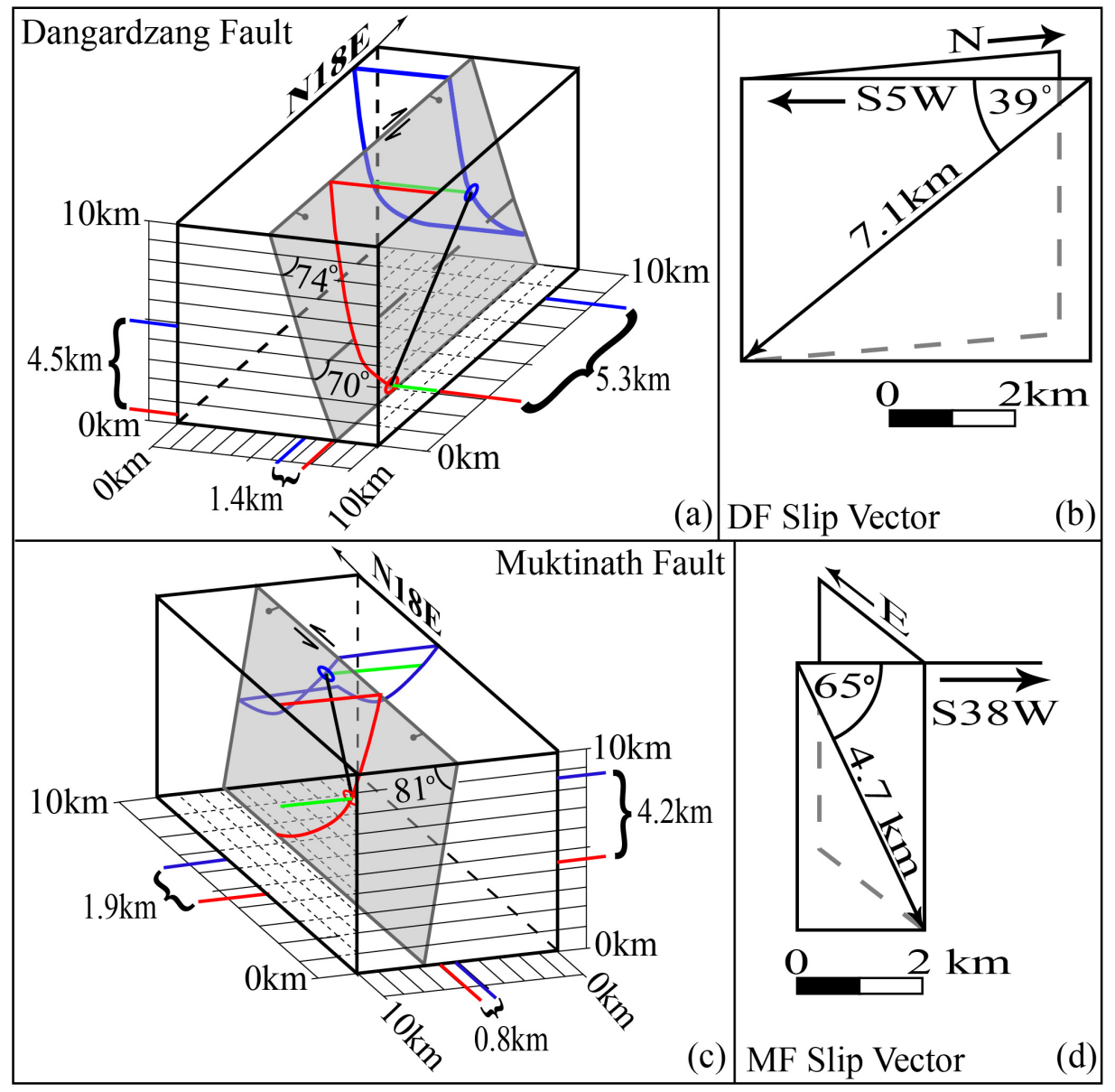

Fig. 7: (a) Block diagram showing geometric relationship with the Kagbeni Fault offset along the Dangardzang Fault. Gray plane represents the Dangardzang Fault which dips $74^{\circ} \mathrm{E}$ and $71^{\circ} \mathrm{E}$. The position of the Kagbeni Fault in the hanging wall of the Dangardzang Fault is represented in red. The position of the Kagbeni Fault in the footwall of the Dangardzang is represented in dark blue. Green represents the position of the piercing line defined by the intersection of the Bagung-Jomsom contact with the Kagbeni Fault. The respective positions of the piercing lines on either side of fault are projected onto axes representing increments of dip-slip, strike-slip, and extension. The magnitude of dip-slip is $4.5 \mathrm{~km}$, strike-slip is $5.3 \mathrm{~km}$, and extension $1.4 \mathrm{~km}$. (b) Dangardzang Fault slip vector which plunges $39^{\circ}$, trends $\mathrm{S} 005 \mathrm{~W}$, with a magnitude of $7.1 \mathrm{~km}$. (c) Block diagram showing geometrical relationship with the Kagbeni Fault offset along the Muktinath Fault. Gray plane represents the Muktinath Fault which dips $81^{\circ} \mathrm{W}$. The position of the Kagbeni Fault in the hanging wall of the Muktinath Fault is represented in red. The position of the Kagbeni Fault in the footwall of the Muktinath is represented in dark blue. Green represents the position of the piercing line defined by the intersection of the Bagung-Jomsom contact with the Kagbeni Fault. The respective positions of the piercing lines on either side of fault are projected onto axes representing increments of dip-slip, strike-slip, and extension. The magnitude of dip-slip is $4.2 \mathrm{~km}$, strike-slip is $1.9 \mathrm{~km}$, and extension $0.8 \mathrm{~km}$. (d) Muktinath Fault slip vector that plunges $65^{\circ}$, trends $\mathrm{S38} \mathrm{W}$, with a magnitude of $4.7 \mathrm{~km}$. 
the Kagbeni Fault, over $\sim 135 \mathrm{~km}$ total length. The central portion of the Dangardzang Fault lies near the town of Mustang and could be where the fault slip is greatest. Unfortunately we did not have access to this area. The central portion of the Muktinath Fault lies near the Kagbeni Fault and thus our slip estimate may likely be close to the maximum slip.

\section{DISCUSSION}

Although the Thakkhola Graben is arguably the most prominent physiographic feature crossing the Himalaya, our results show that it has accommodated only a small amount of arc-parallel extension and vertical thinning compared to structures immediately to its west in the Gurla Mandhata region. This variation in the magnitude of extension is not consistent with an extensional pattern predicted by radial spreading or gravitational collapse models which predict uniform extension across the length of the thrust wedge. This pattern of decreasing extension from west to east is consistent with the predictions of the oblique convergence kinematic model (McCaffrey and Nabelek, 1998; Seeber and Pêcher, 1998; Fan and Murphy, 2021), which explains that the arc-parallel velocity gradient is driven by the relative convergence angle between India and the Himalayan thrust wedge. Strike-slip accommodated along the steeply-dipping Dangardzang and Muktinath Faults may facilitate lateral differences in the foreland propagation of underlying thrust sheets, and thus they operate as tear faults as suggested by Hurtado et al. (2001). Moreover we think that the Dangardzang and Muktinath faults may link to deeper steeply dipping structures in the thrust wedge as suggested by the collocation of the graben with inferred rupture barriers for historical earthquakes (Gahalaut and Kundu, 2012) or even below it as suggested by the collocation of the graben with subducted Indian Basement ridges (Godin and Harris, 2014). The possibility of the Thakkhola faults operating as tear faults should be explored more as it may complicate the use of pre-graben structures as offset strain markers.

\section{CONCLUSIONS}

Our study shows that the total east-west extension across the graben-bounding faults is low and is as predicted by oblique convergence models. Structural analysis of an offset suite of structures in the TSS constrains the magnitude of strain accommodated by the faults bounding Thakkhola Graben: 7.2 kilometers of arc-perpendicular strain via strike-slip faulting, 8.7 kilometers of vertical thinning via dip-slip faulting, and 2.2 kilometers of arc-parallel extension. Field work reveals the presence of the Kagbeni reverse fault separating a change in TSS fold vergence. We associate this synform with the Dolpo-Mugu-
Manang synclinorium. The Kagbeni Fault is offset by the Dangardzang and Muktinath Faults with an oblique-normal sense of shear. Additionally, our reconnaissance reveals a south-dipping metamorphic discontinuity, termed the Mustang Detachment, in the Dangardzang footwall separating the TSS and upper GHC akin to the Annapurna/Phu Detachments. Graben-parallel kink folds are observed in the basinfill formations. We interpret these folds to be faultbend folds forming as the Dangardzang hanging wall moves over slight bends in the fault surface. Forward modeling of the hanging wall deformation allows establishment of the Dangardzang Fault geometry at depth. We establish that the Dangardzang Fault does not sole into the STDS beneath Thakkhola Graben.

\section{ACKNOWLEDGEMENTS}

We greatly appreciate logistical support provided by Bhim Chand with Earth Paradise Treks and Expeditions Ltd. We also thank Calvin Silver for his field assistance. This work was supported in part by a GSA Student Research Grant to Thomas Baltz. The authors are greatly appreciative of reviews of an earlier version of our manuscript by Alex Webb and Mary Hubbard.

\section{AUTHOR'S CONTRIBUTIONS}

TB and MAM carried out the fieldwork. TB performed the fault modeling and slip analysis. All authors wrote the paper.

\section{REFERENCES}

Auden, J., 1937, Structure of the Himalaya in Garhwal: Records Geological Survey of India, v. 71, p. 407433.

Bassoullet, J., and Colchen, M., 1974, Les formations tradiorogéniques de la Thakkhola, Himalaya du Népal. 2ème Réun: Sc. Terre., Pont-a-Mousson, France.

Bodenhausen, J., De Booy, T., Egeler, C., and Nijhuis, H., 1964, On the geology of central west Nepal-A preliminary note: Report on 22nd International Geological Congress Delhi, Volume 11, p. 101-122.

Bordet, P., 1972, Some features of the geology of the Annapurna Range, Nepal Himalaya: Him. Geol., v. 2, p. 537-563.

Bordet, P., 1977, Géologie de la Dalle du Tibet (Himalaya Central): Mem. Hors Ser. Soc. Geol. Fr., no. 8, p. 235-250.

Bordet, P., Colchen, M., Krummenacher, D., Le Fort, P., Mouterde, R., and Remy, M., 1971, Recherches géologiques dans l'Himalaya du Népal, région de la Thakkhola, Édition du Centre national de la recherche scientifique, $279 \mathrm{p}$.

Brown, R. L., and Nazarchuk, J. H., 1993, Annapurna detachment fault in the Greater Himalaya of central Nepal: Geological Society, London, Special 
Publications, v. 74, no. 1, p. 461-473, https://doi. org/10.1144/gsl.sp.1993.074.01.31.

Burchfiel, B. C., and Royden, L. H., 1985, North-south extension within the convergent Himalayan region: Geology, v. 13, no. 10, p. 679-682, https://doi. org/10.1130/0091-7613(1985)13<679:Newtch $>2.0$ .Co;2.

Burchfiel, B. C., Zhiliang, C., Hodges, K. V., Yuping, L., Royden, L. H., Changrong, D., and Jiene, X., 1992, The South Tibetan Detachment System, Himalayan Orogen: Extension Contemporaneous With and Parallel to Shortening in a Collisional Mountain Belt: Geological Society of America Special Papers, v. 269, p. 1-41, https://doi.org/10.1130/SPE269-p1.

Caby, R., Pêcher, A., and LeFort, P., 1983, Le grand chevauchement central himalayen. Nouvelles données sur le métamorphisme inverse à la base de la Dalle du Tibet.(The Himalayan Main Central Thrust: new data about the reverse metamorphism at the bottom of the Tibetan Slab): Revue de géologie dynamique et de géographie physique Paris, v. 24, no. 2, p. 89-100.

Cannon, J. M., and Murphy, M. A., 2014, Active lower crustal deformation and Himalayan seismic hazard revealed by stream channels and regional geology: Tectonophysics, v. 633, p. 34-42, https://doi. org/10.1016/j.tecto.2014.06.031.

Chamlagain, D., and Hayashi, D., 2005, Fault development in the Thakkhola half graben: insights from numerical simulation: Bulletin of the College of Science. University of the Ryukyus, v. 79, p. 57-90.

Colchen, M., 1975, Palaeogeographic and structural evolution of the Tibetan area of the Nepal Himalaya (Annapurna region): Himalayan Geology, v. 2, p. 583-103.

Colchen, M., 1981, Geological Map of AnnapurnaManaslu-Ganesh Himalaya of Nepal: Zagros, Hindu Kush, Himalaya Geodynamic Evolution, v. 3, p. 323.

Colchen, M., 1999, The Thakkhola-Mustang graben in Nepal and the late Cenozoic extension in the Higher Himalayas: Journal of Asian Earth Sciences, v. 17, no. 5-6, p. 683-702, https://doi.org/10.1016/S13679120(99)00037-1.

Colchen, M., Fort, M., and Freytet, P., 1979, Sédimentation et tectonique plioquaternaire dans le Haut Himalaya: l'exemple du fossé de la Thakkhola (Himalaya du Népal).-7ème Réun: Sc. de la Terre, Lyon, France, v. 121.

Colchen, M., Fort, M., and Freytet, P., 1980, Evolution Paleogeographique et Structural du Fosse de la Thakkhola-Mustang (Himalaya du Nepal) implications sur l'Evolution Recente de la Chanie Himalayanne: C.R. Acad. Sci. Paris, no. 280, p. 311-314.

Colchen, M., LeFort, P., and Pêcher, A., 1986, Recherches geologiques dans l'Himalaya du Nepal: AnnapurnaManaslu-Ganesh Himal; notice de la carte géologique au 1/200 000e; edition bilingue françaisanglais, Ed. du Centre national de la recherche scientifique.

Coleman, M., and Hodges, K., 1995, Evidence for Tibetan Plateau Uplift before 14-Myr Ago from a New Minimum Age for East-West Extension: Nature, v. 374, no. 6517, p. 49-52, https://doi. org/10.1038/374049a0.

Copley, A., and McKenzie, D., 2007, Models of crustal flow in the India-Asia collision zone: Geophysical Journal International, v. 169, no. 2, p. 683-698, https://doi.org/10.1111/j.1365-246X.2007.03343.x.

Debon, F., Le Fort, P., Sheppard, S. M. F., and Sonet, J., 1986, The Four Plutonic Belts of the TranshimalayaHimalaya: a Chemical, Mineralogical, Isotopic, and Chronological Synthesis along a Tibet-Nepal Section: Journal of Petrology, v. 27, no. 1, p. 219250, https://doi.org/10.1093/petrology/27.1.219.

Debon, F., Le Fort, P., Sonet, J., Liu, G., Jin, C., and Xu, R., 1981, About the lower Paleozoic age of the Kangmar granite (Lhagoi Kangri plutonic belt, South Tibet, China): Terra Cognita, v. 14, p. 67-68.

Debon, F., Sonet, J., Liu, G., Jin, C., and Xu, R., 1984, Caracteres chimico-mineralogiques et datations par Rb-Sr des trois ceintures plutoniques du Tibet meridional: Mission franco-chinoise au Tibet 1980: Etude géologique et géophysique de la croûte terrestre et du manteau supérieur du Tibet et de l'Himalaya, p. 309-317.

Dewey, J. F., 1988, Extensional collapse of orogens: Tectonics, v. 7, no. 6, p. 1123-1139, https://doi. org/10.1029/TC007i006p01123.

Fan, S., and Murphy, M. A., 2021, Three-dimensional strain accumulation and partitioning in an arcuate orogenic wedge: An example from the Himalaya: GSA Bulletin, v. 133, no. 1-2, p. 3-18, https://doi. org/10.1130/b35528.1.

Fort, M., Bassoullet, J., Colchen, M., and Freytet, P., 1980, Sedimentological and structural evolution of the Thakkhola Mustang Graben (Nepal Himalaya) during late Neogene and Quaternary: Congres Geologique International, v. 2, p. 652.

Fort, M., 1996, Late Cenozoic environmental changes and uplift on the northern side of the central Himalaya: a reappraisal from field data: Palaeogeography, Palaeoclimatology, Palaeoecology, v. 120, no. 1, p. 123-145, https://doi.org/10.1016/00310182(94)00038-7.

Fort, M., Freytet, P., and Colchen, M., 1982, Structural and sedimentological evolution of the Thakkhola Mustang graben (Nepal Himalayas): Zeitschrift für Geomorphologie, v. 42, p. 75-98.

Fuchs, G., 1964, Note on the geology of the Palaeozoics and Mesozoics of the Tibetan zone of the Dolpo region (Nepal-Himalaya): Sonderabdruck aus den Verhandlungen der Geologischen bundesanstalt, v. 1, p. 6-9.

Fuchs, G., 1977, Traverse of Zanskar from the Indus to the Valley of Kashmir - a preliminary note: Jahrbuch der Geologischen Bundesanstalt, v. 120, no. 2, p. 219-229.

Fuchs, G., and Sinha, A. K., 1974, On the geology of 
Nainital (Kumaun Himalaya): Himalayan Geology, v. 4 , p. $563-580$.

Gahalaut, V. K., and Kundu, B., 2012, Possible influence of subducting ridges on the Himalayan arc and on the ruptures of great and major Himalayan earthquakes: Gondwana Research, v. 21, no. 4, p. 1080-1088, https://doi.org/10.1016/j.gr.2011.07.021.

Gansser, A., 1964, Geology of the Himalayas, New York, Wiley Interscience, $289 \mathrm{p}$.

Garzanti, E., Le Fort, P., and Sciunnach, D., 1999, First report of Lower Permian basalts in South Tibet: tholeiitic magmatism during break-up and incipient opening of Neotethys: Journal of Asian Earth Sciences, v. 17 , no. 4, p. 533-546.

Garzione, C. N., DeCelles, P. G., Hodkinson, D. G., Ojha, T. P., and Upreti, B. N., 2003, East-west extension and Miocene environmental change in the southern Tibetan plateau: Thakkhola graben, central Nepal: GSA Bulletin, v. 115 , no. 1, p. 3-20, https://doi. org/10.1130/0016-7606(2003)115<0003:EWEAM $\mathrm{E}>2.0 . \mathrm{CO} ; 2$.

Garzione, C. N., Quade, J., DeCelles, P. G., and English, N. B., 2000, Predicting paleoelevation of Tibet and the Himalaya from $\delta 180$ vs. altitude gradients in meteoric water across the Nepal Himalaya: Earth and Planetary Science Letters, v. 183, no. 1-2, p. 215-229, https://doi.org/10.1016/S0012$821 \mathrm{X}(00) 00252-1$.

Godin, L., 2003, Structural evolution of the Tethyan sedimentary sequence in the Annapurna area, central Nepal Himalaya: Journal of Asian Earth Sciences, v. 22, no. 4, p. 307-324, https://doi.org/10.1016/ S1367-9120(03)00066-X.

Godin, L., Brown, R. L., and Hanmer, S., 1999, High strain zone in the hanging wall of the Annapurna detachment, central Nepal Himalaya: Geological Society of America Special Papers, v. 328, p. 199210, https://doi.org/10.1130/0-8137-2328-0.199.

Godin, L., and Harris, L. B., 2014, Tracking basement cross-strike discontinuities in the Indian crust beneath the Himalayan orogen using gravity data - relationship to upper crustal faults: Geophysical Journal International, v. 198, no. 1, p. 198-215, https://doi.org/10.1093/gji/ggu131.

Godin, L., Parrish, R. R., Brown, R. L., and Hodges, K. V., 2001, Crustal thickening leading to exhumation of the Himalayan Metamorphic core of central Nepal: Insight from U-Pb Geochronology and40Ar/39Ar Thermochronology: Tectonics, v. 20, no. 5, p. 729747, https://doi.org/10.1029/2000tc001204.

Gradstein, F. M., Rad, U. v., Westermann, G. E., Wiedmann, J., and Gibling, M. R., 1992, Stratigraphy and depositional history of the Mesozoic continental margin of central Nepal: Geologisches Jahrbuch. Reihe B, Regionale Geologie Ausland, no. 77, p. 1-141.

Hagen, T., 1954, Über Gebirgsbildung und Talsysteme im Nepal Himalaya: Geographica helvetica, v. 9, no. 1, p. 325-332.

Hagen, T., 1959, Über den geologischen Bau des Nepal-
Himalaya: Jarhbuch St-Gallishcen Naturforschende Gesellschaft, v. 76, p. 3-48.

Hagen, T., 1969, Geology of Nepal Himalaya. Report on the geological Survey of Nepal Preliminary Reconnaissance. Zurich: Memoires de la Soc. Helvetique des science Naturelles, v. 86, p. 185.

Hagen, T., Wahlen, F. T., and Corti, W. R., 1961, Nepal: the kingdom in the Himalayas, Kümmerly \& Frey.

Harrison, T. M., Grove, M., Lovera, O. M., Catlos, E. J., and D'Andrea, J., 1999, The origin of Himalayan anatexis and inverted metamorphism: Models and constraints: Journal of Asian Earth Sciences, v. 17, no. 5-6, p. 755-772, https://doi.org/10.1016/S13679120(99)00018-8.

Harrison, T. M., Lovera, O. M., and Grove, M., 1997, New insights into the origin of two contrasting Himalayan granite belts: Geology, v. 25, no. 10, p. 899-902.

Heim, A., and Gansser, A., 1939, Geological Observations of the Swiss Expedition, Volume 73, p. 245.

Hodges, K. V., Hurtado, J. M., and Whipple, K. X., 2001, Southward extrusion of Tibetan crust and its effect on Himalayan tectonics: Tectonics, v. 20, no. 6, p. 799-809, https://doi.org/10.1029/2001TC001281.

Hodges, K. V., Parrish, R. R., and Searle, M. P., 1996, Tectonic evolution of the central Annapurna Range, Nepalese Himalayas: Tectonics, v. 15, no. 6, p. 1264-1291, https://doi.org/10.1029/96tc01791.

Hurtado, J. M., Hodges, K. V., and Whipple, K. X., 2001, Neotectonics of the Thakkhola graben and implications for recent activity on the South Tibetan fault system in the central Nepal Himalaya: GSA Bulletin, v. 113, no. 2, p. 222-240, https://doi. org/10.1130/0016-7606(2001)113<0222:NOTTGA $>2.0 . \mathrm{CO} ; 2$.

Ichac, M., and Pruvost, P., 1951, Résultats géologiques de l'expédition française de 1950 à l'Himalaya: Comptes rendus hebdomadaires des séances de l'Académie des sciences, v. 232, no. 19, p. 17211724.

Jade, S., Bhatt, B. C., Yang, Z., Bendick, R., Gaur, V. K., Molnar, P., Anand, M. B., and Kumar, D., 2004, GPS measurements from the Ladakh Himalaya, India: Preliminary tests of plate-like or continuous deformation in Tibet: GSA Bulletin, v. 116, no. 1112, p. 1385-1391, https://doi.org/10.1130/b25357.1.

Klootwijk, C. T., Conaghan, P. J., and Powell, C. M., 1985, The Himalayan Arc: large-scale continental subduction, oroclinal bending and back-arc spreading: Earth and Planetary Science Letters, v. 75 , no. 2 , p. 167-183, https://doi.org/10.1016/0012$821 \mathrm{X}(85) 90099-8$.

Le Fort, P., 1975, Himalayas: the collided range. Present knowledge of the continental arc: American Journal of Science, v. 275, no. 1, p. 1-44.

Le Fort, P., 1981, Manaslu leucogranite: A collision signature of the Himalaya: A model for its genesis and emplacement: Journal of Geophysical Research: Solid Earth, v. 86, no. B11, p. 10545-10568, https:// doi.org/10.1029/JB086iB11p10545. 
Geometry, kinematics, and magnitude of extension across the Thakkhola Graben

Le Fort, P., 1986, Metamorphism and magmatism during the Himalayan collision: Geological Society, London, Special Publications, v. 19, no. 1, p. 159172, https://doi.org/10.1144/gsl.Sp.1986.019.01.08.

Le Fort, P., Cuney, M., Deniel, C., France-Lanord, C., Sheppard, S., Upreti, B., and Vidal, P., 1987, Crustal generation of the Himalayan leucogranites: Tectonophysics, v. 134, no. 1, p. 39-57.

Le Fort, P., and France-Lanord, C., 1995, Granites from Mustang and surrounding regions (Central Nepal): Journal of Nepal Geological Society, v. 11, p. 53-57.

McCaffrey, R., and Nabelek, J., 1998, Role of oblique convergence in the active deformation of the Himalayas and southern Tibet plateau: Geology, v. 26, no. 8, p. 691-694, https://doi.org/10.1130/00917613(1998)026<0691:roocit $>2.3$.co;2.

Molnar, P., 1984, Structure and tectonics of the Himalaya: Constraints and implications of geophysical data: Annual Review of Earth and Planetary Sciences, v. 12 , no. 1, p. 489-516.

Murphy, M. A., and Copeland, P., 2005, Transtensional deformation in the central Himalaya and its role in accommodating growth of the Himalayan orogen: Tectonics, v. 24, no. 4, p. TC4012, https://doi. org/10.1029/2004tc001659.

Murphy, M. A., and Harrison, M. T., 1999, Relationship between leucogranites and the Qomolangma detachment in the Rongbuk Valley, south Tibet: Geology, v. 27, no. 9, p. 831-834, https://doi. org/10.1130/0091-7613(1999)027<0831:rblatq $>2.3$ .co;2.

Murphy, M. A., Saylor, J. E., and Ding, L., 2009, Late Miocene topographic inversion in southwest Tibet based on integrated paleoelevation reconstructions and structural history: Earth and Planetary Science Letters, v. 282, no. 1-4, p. 1-9, https://doi. org/10.1016/j.eps1.2009.01.006.

Murphy, M. A., Taylor, M. H., Gosse, J., Silver, C. R. P., Whipp, D. M., and Beaumont, C., 2014, Limit of strain partitioning in the Himalaya marked by large earthquakes in western Nepal: Nature Geoscience, v. 7, no. 1, p. 38-42, https://doi.org/10.1038/ Ngeo2017.

Murphy, M. A., Yin, A., Kapp, P., Harrison, M. T., Ding, L., and Guo, J., 2000, Southward propagation of the Karakoram fault system, southwest Tibet: Timing and magnitude of slip: Geology, v. 28, no. 5, p. 451-454, https://doi.org/10.1130/00917613(2000)28<451:SPOTKF $>2.0$. CO 2 .

Ratschbacher, L., Frisch, W., Liu, G., and Chen, C., 1994, Distributed deformation in southern and western Tibet during and after the India-Asia collision: Journal of Geophysical Research: Solid Earth, v. 99, no. B10, p. 19917-19945, https://doi. org/10.1029/94JB00932.

Replumaz, A., and Tapponnier, P., 2003, Reconstruction of the deformed collision zone between India and Asia by backward motion of lithospheric blocks: Journal of Geophysical Research: Solid Earth, v. 108, no. B6, https://doi.org/10.1029/2001JB000661.

Schärer, U., Xu, R.-H., and Allègre, C. J., 1986, U(Th)Pb systematics and ages of Himalayan leucogranites, South Tibet: Earth and Planetary Science Letters, v. 77, no. 1, p. 35-48, https://doi.org/10.1016/0012821X(86)90130-5.

Schill,E.,Appel,E., Crouzet, C., Gautam, P., Wehland, F., and Staiger, M., 2004, Oroclinal bending versus regional significant clockwise rotations in the Himalayan arc-Constraints from secondary pyrrhotite remanences: Geological Society of America Special Papers, v. 383, p. 73-85, https://doi.org/10.1130/08137-2383-3(2004)383[73:obvrsc]2.0.co;2.

Searle, M. P., and Godin, L., 2003, The South Tibetan Detachment and the Manaslu Leucogranite: A structural reinterpretation and restoration of the Annapurna-Manaslu Himalaya, Nepal: Journal of Geology, v. 111, no. 5, p. 505-523, https://doi. org/10.1086/376763.

Seeber, L., and Pêcher, A., 1998, Strain partitioning along the Himalayan arc and the Nanga Parbat antiform: Geology, v. 26, no. 9, p. 791-794, https://doi. org/10.1130/0091-7613(1998)026<0791:Spatha $>2$. 3. $\mathrm{Co} ; 2$.

Silver, C. R. P., Murphy, M. A., Taylor, M. H., Gosse, J., and Baltz, T., 2015, Neotectonics of the Western Nepal Fault System: Implications for Himalayan strain partitioning: Tectonics, v. 34, no. 12, p. 24942513, https://doi.org/10.1002/2014tc003730.

Strachey, R., 1851, On the Geology of Part of the Himalaya Mountains and Tibet: Quarterly Journal of the Geological Society, v. 7, no. 1-2, p. 292-310, https:// doi.org/10.1144/gsl.Jgs.1851.007.01-02.54.

Upreti, B. N., 1999, An overview of the stratigraphy and tectonics of the Nepal Himalaya: Journal of Asian Earth Sciences, v. 17, no. 5, p. 577-606, https://doi. org/10.1016/S1367-9120(99)00047-4.

Xiao, H., and Suppe, J., 1992, Origin of rollover: AAPG Bulletin, v. 76, no. 4, p. 509-529.

Yin, A., 2000, Mode of Cenozoic east-west extension in Tibet suggesting a common origin of rifts in Asia during the Indo-Asian collision: Journal of Geophysical Research, v. 105, no. B9, p. 21745 21721,21759 .

Yin, A., Harrison, M. T., Murphy, M. A., Grove, M., Nie, S., Ryerson, F., Wang, X. F., and Chen, Z. L., 1999, Tertiary deformation history of southeastern and southwestern Tibet during the Indo-Asian collision: Geological Society of America Bulletin, v. 111, no. 11, p. 1644-1664, https://doi.org/10.1130/00167606(1999) $111<1644$ :Tdhosa $>2.3 . \mathrm{Co}$;2.

Zhao, W., Nelson, K. D., Che, J., Quo, J., Lu, D., Wu, C., and Liu, X., 1993, Deep seismic reflection evidence for continental underthrusting beneath southern Tibet: Nature, v. 366 , no. 6455 , p. 557-559. 
